\title{
Iklan Sebagai Media Dakwah \\ (Analisis Semiotika Iklan Digital Dan Konsep Dakwah Pada Produk Kosmetik Wardah)
}

\author{
Luthfi Ulfa Ni'amah ${ }^{\mathrm{a}, 1, *}$, Nur Laili, ${ }^{\mathrm{b}, 2}$ \\ ${ }^{a}$ Jurusan Komunikasi dan Penyiaran Islam, Fakultas Ushuluddin, Adab \& Dakwah \\ Institut Agama Islam Negeri Tulungagung,66221, Indonesia \\ ${ }^{b}$ Jurusan Komunikasi dan Penyiaran Islam, Fakultas Ushuluddin, Adab \& Dakwah \\ Institut Agama Islam Negeri Tulungagung,66221, Indonesia \\ ${ }^{1}$ luthfiulfaniamah86@gmail.com ${ }^{2}$ nur.laili717@gmail.com
}

\section{INFO ARTIKEL}

Riwayat Artikel:

Diterima: Januari 2019

Direvisi : Februari 2019

Disetujui: Maret 2019

Kata Kunci:

Iklan Digital

Analisa Semiotik

Konsep Dakwah

Keywords:

Digital Advertisement

Semiotic Research

Da'wah Concept
AB STR AKSI

Dakwah merupakan seruan untuk mengajak manusia melakukan amar ma'ruf dan nahi munkar. Aktifitas mengajak ini dapat dilakukan dengan berbagai cara dan menggunakan berbagai media, salah satu alternatif media yang dapat digunakan dalam berdakwah adalah dengan menggunakan iklan.Penelitian ini ingin mengetahui apa sajakah makna tanda yang terkandung dalam iklan digital produk kosmetik Wardah tahun 2018 sebagai media dakwah. Dan juga ingin mengetahui konsep dakwah apayang ditampilkan dalam iklan digital pada produk kosmetik Wardah tersebut. Dengan menggunakan analisis semiotik yang dikembangkan oleh RolandBarthes(kode hermeneutik, kode kulturzl, kode semik, kode proaretik dan kode simbolik,selain inginmengetahui dan memahami iklan sebagai media dakwah Islam juga diharapkan penelitian ini dapat memberikan pemahamandan meningkatkan kesadaran pada masyarakat untuk bersikap selektif dan juga kritis dalam menghadapi informasi yang diperoleh, terlebih juga agar tidak terjadi salah persepsi dalam memahami isi pesan yang disampaikan dalam iklan maupun media yang lainnya.Penelitian ini juga ingin memberikan kontribusi bagi pengiklan yang lain, bahwa iklan Wardah dapat dijadikan referensi dalam mempromosikan produk terutama produk kecantikan dan juga diharapkan penelitian ini dapat memberikan gambaran dan deskripsi dalam memahami dan membacamakna dari konsep dakwah yang terdapat dalam iklan kosmetik Wardah serta dapat menjadi bahan referensi dalam melakukan penelitian tentang semiotika dengan pendekatan analisis semiotik Roland Barthes

\section{Abstract:}

Da'wah is a call to invite people to do amar ma'ruf and nahi munkar. This inviting activity can be done in various ways and using a variety of media, one alternative media that can be used in da'wah is by using advertisements. This research wants to find out what the meaning of the sign contained in Wardah cosmetics digital product 2018 as a propaganda media. And also want to know what the da'wah concept is displayed in digital advertising on Wardah's cosmetic products.

By using a semiotic analysis developed by Roland Barthes (hermeneutic code, kulturzl code, semic code, proaretic code and symbolic code, in addition to wanting to know and understand advertising as an Islamic propaganda media, it is also hoped that this research can provide understanding and increase awareness in the community to be selective and also critical in dealing with the information obtained, especially so that there is no misperception in understanding the contents of the message conveyed in advertisements and other media.

This study also wants to contribute to other advertisers, that Wardah advertisements can be used as a reference in promoting products, especially beauty products, and it is also hoped that this research can provide an overview and description in understanding and understanding the da'wah concepts contained in Wardah cosmetics advertisements and can be used as ingredients reference in conducting research on semiotics with Roland Barthes's semiotic analysis approach 


\section{Pendahuluan}

Begitu gencarnya perkembangan teknologi digital, membuat model pemasaran kini semakin meningkat. Salah satunya adalah model pemasaran digital, yakni aktivitas promosi baik brand maupun produk melalui media digital. Dari tahun ke tahun pengguna video online mengalami peningkatan yang signifikan. Dari data Warc dan MMA menunjukkan bahwa iklan digital dari tahun 2017 sampai 2018 mengalami peningkatan dari 60 persen menjadi 65 persen. ${ }^{1}$ Keberadaan massa yang dominan ini menjadi sasaran bagi para pemasar iklan untuk memasarkan produknya.

Iklan digital menjadi pilihan utama bagi para pebisnis untuk pemasaran brand maupun produknya. PubMatic memperkirakan belanja iklan digital di Indonesia tahun 2019 mencapai 26 persen atau \$2 miliar dibanding tahun lalu. Indonesia mengalami angka pertumbuhan tertinggi dibanding negara lain mengalahkan negara-negara Eropa. Dalam hal ini Indonesia masih kalah dibanding dengan pertumbuhan US dan Cina. US menempati peringkat tertinggi mencapai $\$ 110,99$ miliar. Sedangkan Cina berada diurutan nomer dua mencapai $\$ 60,81$ miliar di tahun 2019. ${ }^{2}$ Namun dari sisi persentase negara tersebut masih kalah dibanding dengan negara berkembang seperti Indonesia dan India. Jika dilihat dari \%YoY change, Indonesia berada diposisi puncak dengan persentase pertumbuhan 26 persen.

Iklan erat kaitannya dengan penggunaan model perempuan. Iklan kecantikan menjadi daya tarik konsumen sejak ratusan tahun. Setidaknya Maybelline telah mengeluarkan iklan kecantikan sejak 1920 dengan model perempuan seperti Hedy Lamarr, Great Lash, Lynda Carter, Gigi Hadid dan lain-lainnya. ${ }^{3}$ Rata-rata model yang dipakai merupakan wanita berpengaruh yang memiliki kecantikan khas masing-masing dari berbagai negara.Karena kecantikan perempuan yang dicitrakan oleh iklan, Laura Mulvey menyebutkan bahwa perempuan menjadi "ikon" di media massa. Tubuh perempuan dianggap sebagai "barang seni". Sehingga secara bebas ditampilkan dan dieksploitasi. sementara Nurul Arifin menyatakan bahwa penggunaan perempuan dalam iklan adalah karena perempuan mempunyai seluruh karakter yang bisa diperjualbelikan. ${ }^{4}$

Iklan Wardah menyebutkan bahwa diawal kehadirannya menampilkan kecantikan sebagai bagian budaya patriarki. Perempuan akan terlihat cantik apabila memiliki sikap dan berpenampilan feminim. ${ }^{5}$ Budaya patriarki memang erat kaitannya dengan agama Islam yang mana terdapat batasan-batasan antara laki-laki dan perempuan. Analisa semiotika dapat melihat makna kecantikan ditunjukkan tidak hanya dari penampilan yang tertutup saja, tetapi juga dari makna yang terkandung dari penampilan tersebut.

Teknologi merupakan wadah baru bagi manusia untuk berkomunikasi dengan khalayak luas. Anwar Arifin menyatakan bahwa ketika umat Islam dapat menguasai ilmu pengetahuan dan teknologi, maka dakwah Islam akan mendapatkan kemudahan. ${ }^{6}$ Dakwah memiliki sifat persuasif, yaitu mengajak manusia dengan cara yang halus atau lebih tepatnya meyakinkan orang lain terhadap sesuatu tanpa memaksa. Sifat yang dimilikinya sama dengan prinsip marketting (pemasaran) yaitu tindakan persuasi untuk mempengaruhi atau membujuk konsumen. Dakwah Islam tidak lagi didefinisikan secara konservatif sebagai tindakan berceramah melainkan dari berbagai aktivitas, yang secara langsung maupun tidak langsung menarik keingintahuan publik tentang Islam.

Inilah yang membuat penulis tertarik untuk melakukan penelitian ini. Penulis ingin mengetahui bagaimana konsep dakwah yang terkandung dalam lima iklan digital produk kosmetik Wardah tahun 2018. Diantaranya iklan Wardah Halal dari Awal, Wardah BB Cake

\footnotetext{
${ }^{1}$ Warc Data, Global Ad Trends Juli/Agustus 2018 - Online Video (Sample), https://www.warc.com/ diakses pada 06 Mei 2019

${ }^{2}$ PubMatic, 2019 Global Digital Ads Trands, https://pubmatic.com/ diakses pada 06 Mei 2019

${ }^{3}$ http://stellar.ie/beauty-fashion/13-maybelline-ads-from-1920-to-now-showing-the-amazing-history-of-beauty/4779 diakses pada 06 Mei 2019

${ }^{4}$ Rendra Widyatama, Bias Gender dalam Iklan, (Yogyakarta: Media Pressindo, 2006) Hal. 2

${ }^{5}$ Kamaluddin Tajibu, Syafariana, Pesan Dakwah Pada Iklan Kosmetik Wardah "Sebuah Kajian Semiotika", Hal. 3-4

${ }^{6}$ Ibid, hal. 3
} 
Powder, Wardah Exclusive Matte Lip Cream, Wardah Ramadhan Cantik dari Hati, dan Wardah Cantik dari Hati - The Power of Smile. Dengan menggunakan analisis semiotika sebagai instrumen untuk analisis iklan yang secara khusus dikembangkan oleh Roland Barthes mengenai lima kode dalam mencari makna tanda dalam teks.

Tujuan pada penelitian ini adalah untuk mengetahui dan memahami arti dari lima kode yakni; Kode Hermeneutik, Kode Semantik, Kode Simbolik, Kode Proaretik, dan dan Kode Budaya yang terdapat dalam lima iklan digital pada produk kosmetik terkhusus Wardah tahun 2018. Untuk itu selain mengetahui makna konsep dakwah yang terdapat pada iklan sebagai alternatif media dalam menyampaikan dakwah, peneliti juga akan menganalisis isi yang terkandungandalam teks serta visualisasinya dalam lima iklan produk kosmetik Wardah tahun 2018. Diharapkan penelitian ini dapat memberikan gambaran dan deskripsi memahami dan membacamakna dari konsep dakwah yang terdapat dalam iklan kosmetik Wardah serta dapat menjadi bahan referensi dalam melakukanpenelitian tentang semiotika dengan pendekatan analisis semiotik Roland Barthes.

\section{Pembahasan}

\section{A. Konsep Dakwah}

Kata dakwah apabila ditinjau dari segi bahasa berasal dari bahasa Arab "da'wah". Da'wah mempunyai tiga huruf asal, yaitu dal, 'ain, dan wawu. Dal, 'ain, dan wawu pada kata dakwah memiliki makna memanggil, mengundang, minta tolong, meminta, memohon, menamakan, menyuruh datang, mendorong, menyebabkan, mendatangkan, mendoakan, menangisi dan meratapi. Al-Qur'an mengembangkan makna dari kata da'wah untuk berbagai penggunaan.

Dalam bukunya Komunikasi Dakwah, Wahyu Ilaihi ${ }^{7}$ mengitip pendapatnya Sayyid Qutb memberikan batasan dengan hanya mengajak atau menyeru orang lain bukan untuk mengikuti da'i ataupun sekelompok orang melainkan agar masuk ke dalam jalan (sabil) Allah SWT menjadi arti dakwahsecara terminologis.Sedangkan upaya berupa ucapan atau pekerjaan mempengaruhi manusia agar mengikuti Islam adalah makna dakwah menurut Ahmad Ghusuli. Menurut Ismail al-Faruqi, pada hakikatnya dakwah adalah bersifat universal, kebebasandan rasional. Sedangkan Abdul al Badi Shadar membagi dakwah menjadi dua tataran yaitu dakwah fardiyah atau dakwah yang sasaran dan sifatnya lebih pribadidan dakwah ummah atau dakwah yang sasaran dan sifatnya kepada khalayak. Abu Zahroh menyatakan bahwa dakwah itu dapat dibagi menjadi dua hal; pelaksana dakwah, perseorangan, dan organisasi.

Dalam kegiatan berdakwah terdapat unsur-unsur atau komponen yang terkandung dalam dakwah, yaitu:

1) $\mathrm{Da} i$

Da'i adalah orang yang melaksanakan dakwah. Melalui lisan, tulisan maupun perbuatan. ${ }^{8}$ Pendakwah/da'i bisa bersifat individu, kelompok dan juga kelembagaan. Terdapat tiga tingkatan pendakwah/da'i, yakni; Da'iMujtahid, da'I Muttabi', dan da'I Muqallid. Pendakwah Mujtahiddiartikan sebagai orang yang memilikikemampu untuk memberikan dan mencurahkan pemikiran dalam menggali informasi dan pemahaman secara langsung dari Al-Qur'an dan Hadits, yang juga ahli dalam ilmu-ilmu keislaman. Sedangkan da'iMuttabi'adalah da'itidak memiliki kemampuan pemahaman yang sama dengan da'i mujtahid, dia hanya dapat menyampaikan hasil dari produk pemikiran da'i Mujtahid tersebut. Da'i yang ketiga adalah da'i Muqallid, da'i ke tiga ini merupakan seorang da'i yang merasa terpanggil dan memiliki keinginan yang kuat untuk melaksanakan dakwah walaupun dia belum mengetahui dasar hukum suatu permasalahan dan baru memahami isi kandungan AlQur'an dan ajaran Islam secara dangkal.

\footnotetext{
${ }^{7}$ Wahyu Ilaihi, Komunikasi Dakwah, (Bandung: PT Remaja Rosdakarya, 2013), hal. 14

${ }^{8}$ Moh Ali Aziz, Ilmu Dakwah cet. ke-4, (Jakarta: Prenadamedia Group, 2015), hal 216
} 


\section{2) Mad'u}

Mad'u adalah manusia yang menerima pesan dakwah, menjadi mitra dakwah, menjadi sasaran dakwah, baik secara individu maupun kelompok, baik yang beragama Islam maupun tidak. Menurut Acep Aripudin,9 pada mad'u kontemporer sasaran dakwah sekaligus menjadi masalah dakwah yang harus dikaji dengan teliti. Permasalahan dakwah tersebut terletak pada masyarakat kelas bawah yang fokus persoalannya terletak pada kesejahteraan pendidikan dan kesejahteraan pangan.Dalam Tafsir Al-Manar, Muhammad Abduhmenyatakan, secara garis besar, terdapat tiga golongan mad'u yang dihadapi oleh seorang da'i, yaitu ${ }^{10}$ : pertama, golongan cerdik-cendekia, yakni golongan cendekiawan yang cinta akan kebenaran, memiliki kemampuan menangkap persoalan dengan cepat dan tanggap serta memiliki pemikiran yang kritis.Kedua adalahgolongan awam, yaitu golongan orang tingkat pemikirannya masih tergolong rendah, mereka belam mampu menangkap materi dan pengertian-pengertian tinggi yang sulit difahami dan belum mampu berfikir secara mendalam dan kritis. Sedangkan golonganketigaadalahgolongan perpaduan dari golongan pertama dan golongan kedua apabila dilihat dari tingkat kecerdasannya, mereka belum mampu menggali dan memahami sesuatu secara mendalam tetapi mereka senang membahas suatu permasalahan tersebut.

\section{3) Pesan/Materi Dakwah}

Isi yang disampaikan oleh da'i kepada mad'u menjadi pesan atau materi dalam dakwah. Wahyu Ilaihi, ${ }^{11}$ mengutip beberapa pendapat ahli menyatakan bahwa ajaran Islam menjadi inti dari materi dakwah itu sendiri, yaitu aqidah, syariah dam akhlak. pesan akidah yang terkandung dalam rukun iman yang enam, yakni; iman kepada Allah SWT., iman kepada Malaikat-Nya, iman kepada kitab-kitab-Nya, iman kepada Rasul-Nya, iman kepada hari akhir serta iman kepada qadha' dan qadhar.Pesan syariah berkaitan dengan ibadah seperti thaharah, sholat, zakat, puasa, haji serta mu'amalah.Sedangkan pesan akhlak diantaranya adalah akhlak terhadap Allah SWT dan akhlak terhadap makhluk. Selain itu terdapat beberapa jenis pesan dakwah, diantaranya adalah Ayat-ayat Al-Qur'an, Hadits, pendapat para sahabat, pendapat ulama', hasil penelitian ilmiah, kisah dan pengalaman teladan, berita dan peristiwa, karya sasra dan karya seni.

\section{4) Media Dakwah}

Dalam pandangan komunikasi, Bambang S. Ma'arif mendefinisikan media komunikasi sebagai sarana atau alat yang digunakan oleh seseorang untuk mengantarkan pesan kepada mitranya. ${ }^{12}$ Dakwah juga merupakan proses komunikasi, karenanya Media dakwah juga dapat diartikan sebagai alat yang menjadi perantara penyampaian pesan dakwah dari da'i kepada mad'u.Kestad Suhandang ${ }^{13}$ memberikan analisis terhadap dakwah yang dilakukan oleh Rasulullah pada masa dahulu selain tatap muka juga menggunakan media, karenanya selain berdakwah dalam bentuk komunikasi antar-persona, beliau juga melakukan komunikasi massa dengan menggunakan media khutbah, kisah, situasi musim haji dan lain sebagainya. Media dakwah yang dapat digunakan untuk mencapai tujuan dakwah menurut Ropingi elIshaq dapat diterapkan pada 5 hal, ${ }^{14}$ yaitu Pertama berbentuk lembaga pendidikan, Kedua, lingkungan keluarga maupun lingkungan sosial masyarakat, Ketiga, organisasi sosial, profesi, budaya, politik, keagamaan dan lain sebagainya, Keempat, peristiwa atau hari-hari tertentu dan yang Keliama, media massa. sedangkan menurut Prof Ali Aziz, ${ }^{15}$ Penyampaian isi pesan dakwah dengan menggunakan dan memanfaatkan media dapat menambah jangkauan dakwah yang tidak hanya sebatas tatap muka tetapi juga sampai pada hal-hal yangtidak terbatas oleh

\footnotetext{
${ }^{9}$ Acep Aripudin, Sosiologi Dakwah, (Bandung; Remaja Rosdakarya, 2013), hal. 22

${ }^{10}$ Fathul Bahry An-Nabiry, Meniti Jalan Dakwah Bekal Perjuangan Para Da’i, (Jakarta: Amzah, 2008) hal. 231

${ }^{11}$ Wahyu Ilaihi, Komunikasi Dakwah, (Bandung: PT Remaja Rosdakarya, 2013), hal. 101-102

${ }^{12}$ Bambang S. Ma'arif, Psikologi Komunikasi Dakwah, (Bandung; Remaja Rosdakarya, 2015), Hal. 41

${ }^{13}$ Kustadi Suhandang, Ilmu Dakwah, (Bandung; Remaja Rosdakarya, 2013), hal. 39

${ }^{14}$ Ropingi el-Ishaq, Pengantar Ilmu Dakwah, Studi Komprehensif Dakwah dari Teori ke Praktik, (Malang; Madani, 2016), Hal. 131-138

${ }^{15}$ Moh Ali Aziz, Ilmu Dakwah cet. ke-4, (Jakarta: Prenadamedia Group, 2015), hal, 411
} 
ruang dan waktu. Beberapa mediayang dapat dimanfaatkan untukberdakwah dan menjadi media dakwah diantaranya adalah media lisan, media tulisan, media audio visual, lingkungan keluarga, Uswah dan Qudwah Hasanah (berdakwah dengan bentuk nyata), dan organisasi Islam.

Pada Ilmu Komunikasi, terkait dengan kajian tentang media setidaknya terdapat tiga klasifikasi media yaitu The spoken Words yang diartikan sebagai media terucap, berupa alat yang dapat mengeluarkan bunyi seperti radio dan sejenisnya. Ke dua, The Printed Writing yaitu media tertulis atau berbentuk cetak seperti buku, lukisan, majalah, koran dll. Dan yang ketiga adalah The Audio Visual yaitu media dengar pandang berupa media yang didalamnya terdapat gambar seolah-olah hidup yangdapat di dengar dan dilihat, seperti film,televisi, vidio, youtub dan sejenisnya.

\section{5) Metode Dakwah}

Metode merupakan sebuah cara atau jalan yang bisa digunakan dalam berdakwah, tujuan metode dakwah ialah untuk memepermudah proses berdakwah serta memberikan keserasian cara antara da'i dalam penyampaian pesan dakwahnya serta pada mad'u dalam menerima dan memahami pesan dakwahnya.Al-Bayanuni ${ }^{16}$ memeberikan penjelasan tentang pengertian asalib al-da'wah atau metode dakwah sebagai yang ditempuh oleh da'i dalam menyampaikan dakwahnya atau cara yang digunakan oleh da'i dalam menerapkan strategi dakwah yang di laksanakan untuk keberhasilan dakwahnya .

Secara garis besar terdapat tiga bentuk dakwah; yakni da'wah bi al-lisan (dakwah lisan), da'wah bi al-qalam (dakwah tulisan) dan yang ketiga da'wah bi al-hal (dakwah tindakan).dari ketiga bentuk dakwah tersebut dapat dikembangkan menjadi beberapa teknik dan metode dalam berdakwah, diantaranya metode ceramah, metode diskusi, metode konseling, metode karya tulis, metode pemberdayaan masyarakat, metode kelembagaan dan masih banyak yang lainnya. Al-Qur'an menjelaskan berbagai macam metode dalam berdakwah, salah satunya diterangkan di dalam QS. An-Nahl ayat 125 yang didalamnya diterangkan tentang tiga metode dakwah, yaitu dakwah bil hikmah yang secara singkat diartikan dengan kemampuan seorang da'i dalam memilih dan menyesuaikan materi, media, dan cara dalam penyampaian dakwahnya dengan kemampuan dan kondisi mad'unya. Kedua,Al-mau'izatil hasanahatau pengajaran yang baik diartikan dengan cara berdakwah dalam bentuk pendidikan, memberikan motivasi, memberikan bimbingan, kisah-sah dan lain-lain sebagai ajakan untuk kembali kepada jalan Allah untuk kebaikan hidup di dunia dan di akhirat kela. Sedangkan yang ketiga dalahAl-Mujadalah yang diartikan denganbertukar pendapat, berdebat dan beradu argumentasi dengan baik.

\section{B. Iklan Televisi}

Iklan didefinisikan sebagai pesan yang menawarkan suatu produk yang ditujukan kepada masyarakat lewat suatu media. Iklan tidak sama dengan pengumuman pada umumnya melainkan iklan lebih diarahkan untuk membujuk orang untuk membeli, seperti yang dikatakan Frank Jefkins : "advertising aims to persuade people to buy" ${ }^{17}$ Tujuan periklanan televisi dapat digolongkan menurut sasarannya, yaitu untuk memberi informasi, persuasi, mengingatkan para pembeli, menambah nilai, dan membantu aktivitas lain yang dilakukan perusahaan.

Menurut Faiqotun wahudah, ${ }^{18}$ terdapat lima jenis iklan yang dapat digunakan secara umun, diantaranya; pertama, Iklan tanggung jawab sosial,adalah iklan yang memiliki tujuan atau upaya untuk menyebarkan message yang sifatnya infromatif dan memberikan pendidikan kepada masyarakat agar terbentuk masyarakat baik yang ikut beranggungjawabakan adanya beberapa

\footnotetext{
${ }^{16}$ Al-Bayanuni, Muhammad Abu al-Fath al-.al-Madkhal ila 'Ilm al-Da'wah. Beirut: Muassasah al-Risalah, $1993: 47$.

${ }^{17}$ Lihat Rhenald, Kasali, Manajemen Periklanan Konsep dan Aplikasinya di Indonesia, (Jakarta: Pustaka Utama Grafiti, 1995) hal. 16

${ }^{18}$ Faiqatun Wahidah, Komodifikasi Nilai Agama dalam Iklan Televisi(Studi Analisis Semiotika pada Iklan Wardah), Skripsi Jurusan

Komunikasi dan Penyiaran Islam Fakultas Dakwah dan Komunikasi UIN Walisongo Semarang, 2015, hal, 29-24
} 
permasalahan sosial yang timbul pada masyarakat tertentu. Kedua, Iklan bantahan, iklan bantahan adalah iklan digunakan untuk membantah atau melawan atas sesuatu isu yang merugikan dan memperbaiki citra seseorang, perusahaan atau merek yang tercemar akibat informasi yang tidak benar.Ketiga, Iklan pembelaanmerupakan iklan yang yang bentujuan untuk melakukan pembelaan atas diri komunikator, iklan ini memilik kesamaan dengan iklan bantahan, tetapi tujuannya lebih kepada ingin memberikan pembelaan atas suatu permasalahan yang menimpa komunikator. Keempat, iklan perbaikan merupakaniklan yang bertujuan memberikan perbaikan atas pesan yang telah disampaikan dan disebarluaskan oleh media setelah diketahui terdapat kesalahan pada pesan tersebut.

Iklan semacam ini juga bisa disebut sebagai iklan pembetulan atau iklan ralat. Kelima, iklan keluarga, iklan ini lebih dimaksukan pada iklan yang isi pesannya berupa pemberitahuan dari pihak pembuat iklan tentang peristiwa yang terjadi pada suatu keluarga untuk disampaikan kepada keluarga yang lainnya atau kepada masyarakat luas tentang beberapa kegiatan seperti kelahiran bayi, pernikahan, perceraian, kematian dan lain-lain.

Berdasarkan tujuannya, iklan terbagi menjadi dua, yaitu iklan komersil dan iklan layanan masyarakat (non komersial). Iklan komersial merupakan iklan yang memiliki maksud dan tujuan komersial agar mendatangkan keuntungan bagi produsen apabila iklan yang dibuat tersebut ditayangkan dan dilihat oleh banyak orang. Sedangkan iklan layanan masyarakat atau iklan non komersial, berupa iklan yang memiliki tujuan untuk melakukan pelayanan kepada masyarakat dengan memberikan ide atau gagasan tentang suatu permasalahan agar masyarakat tergerak hatinya untuk melakukan perubahan kepada hal yang lebih baik, seperti himbauan untuk membuang sampah ditempat sampah, menghimbau agar melakukan toleransi, menjaga kebersihan lingkungan dan lain sebagainya.

\section{Konsep Dasar Semiotika Roland Barthes}

Alex Sobur19 dalam bukunya berjudul Semiotika Komunikasi mengutip pendapat Barthes yang dituliskannya dalam buku S/Z (1970) tentang analisnya terhadap buku berjudul Sarrasine karya Honore de Balzak, seorang sastrawan asal Prancis pada abad ke-19. Pada buku tersebut Barthes berupaya untuk menjelaskan secara eksplisit tentang kode narasi pada suatu naskah.Beberapa kode yang di analisisi oleh Barthes diantaranya adalah kode semik, kode hermeneutik, kode proaretik, kode simbolik dan kode budaya.Sebagai tambahan, masing-masing kode menguji perbedaan aspek dari suatu teks (Makaryk, 1993) menjelaskan sebagai berikut:20

1) Kode hermeneutik (HER): digunakan untuk menguji perbedaan-perbedaan, pertanyaanpertanyaan, teka-teki yang muncul yang perlu untuk diselesaikan atau diuraikan. Dengan referensi menurut HER, kita menyelidiki apakah penulis narasi bertanya pertanyaanpertanyaan, atau mengungkapkan keraguan-keraguan pada hasil tulisannya sendiri dengan tetap menghormati pekerjaanya.

2) Kode semik (SEM): digunakan untuk mengidentifikasi makna konotasi dalam teks naratif. Kode ini membantu untuk mengembangkan kualitas dan pendalaman karakter atau sebuah peran. Melibatkan SEM kedalam cerita, kita bisa menyelidiki apa motif yg dominan dari teks naratif itu sendiri.

3) Kode simbol (SYM): digunakan untuk meguji contoh-contoh simbolik yang digambarkan dalam sepasang kelompok dasar yg terletak di struktur dalam teks naratif. Dalam sudut pandang SYM, kita menguji pasangan-pasangan yang paling sering muncul dari sepasang kelompok dasar.

\footnotetext{
${ }^{19}$ Alex Sobur, Semiotika Komunikasi cet. Ke 5, (Bandung: PT Remaja Rosdakarya, 2013) hal. 64-65

${ }^{20}$ Makaryk dalam Tohar, Vered., Merav Asaf, Anat Kainan, Rakefet Shahar,An Alternative Approach for Personal Narrative Interpretation: The Semiotics of Roland Barthes. International Journal of Qualitative Methods.Vol. 6, No. 3, 2007, Hal. 61.
} 
4) Kode proairetic ACT: yang digunakan untuk menguji tindakan dari teks dan mengelompokkanya kedalam makna semantik. Dengan referensi dari makna ACT, kita menguji apa makna utama dari sebuah tindakan yang menonjol dalam sebuah teks naratif itu sendiri.

5) Kode kultural (REF): yang digunakan untuk menguji ketelitian yang mengacu terhadap konteks sosial dan budaya dari teks naratif dan dihubungkan kepada ahli-ahli budaya dan pemikiran umum. Dalam sudut pandang REF, kita menguji untuk ekspresi mana yang penulis usahakan ketika mereka berhubungan dengan dunia pengajaran.

\section{Deskripsi Lima Kode Dalam Iklan Kosmetik Wardah tahun 2018}

\section{1) Wardah Halal dari Awal}

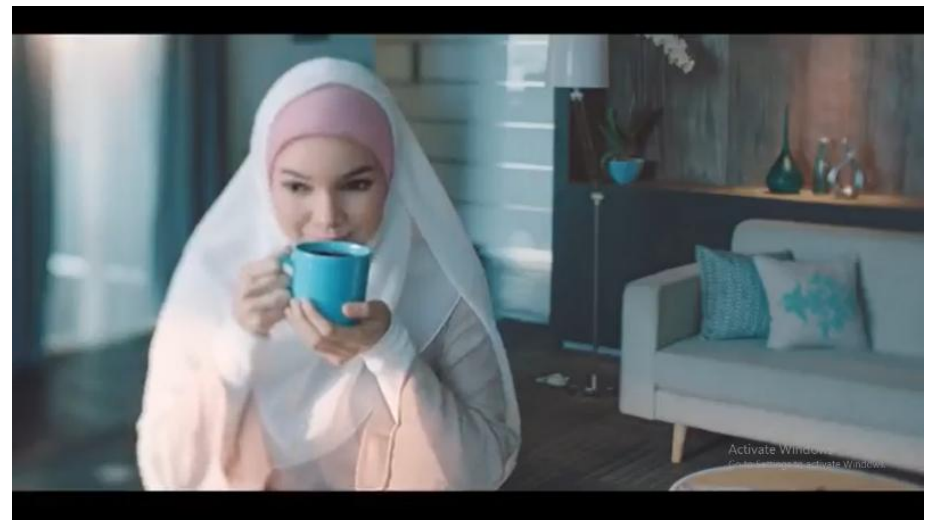

Iklan Wardah dengan tema Halal dari Awal ini mempromosikan banyak produk Wardah, diantaranya Wardah White Secret Day Cream, Wardah Exclusive Matte Lip Cream, Wardah Eye Expert, Wardah Two Way Cake Powder, dan juga Wardah Aloe Vera. Iklan ini dibintangi oleh banyak model salah satunya oleh Dewi Sandra yang merupakan Brand Ambassador Wardah.

a) Kode Hermeneutik, Iklan ini menceritakan tentang Wardah yang melengkapi keberhasilan dan suka cita berbagai wanita. Terdapat banyak adegan dengan cerita yang berbeda-beda untuk setiap produk. Pertama, dimulai dari seorang perempuan naik Bus yang hendak berangkat untuk bekerja kemudian membantu seorang nenek membawa barang berat dan memberikan tempat duduknya didalam Bus. Kedua, adalah seorang gadis yang membagikan hasil capture foto dari kameranya ke instagram mengenaianak kecil yang memberikan es krimnya kepada adiknya. Ketiga, seorang perempuan berhijab yang mengikuti test lomba karate dengan percaya diri. Yang terakhir adalah dimana seorang desainer perempuan muda yang mengerjakan pekerjaannya bersama rekanrekannya dengan penuh semangat.

b) Kode Semantik, Ekspresi yang yang diperankan model masing-masing menunjukkan sebagai perempuan yang mandiri dan percaya diri. Setelah model menggunakan produk Wardah, karakternya sebagai seorang perempuan berkepribadian baik menjadi semakin kuat. Wardah memperkuat karakter dari setiap model dalam iklan tersebut.

c) Kode Simbolik, pertama Model yang digunakan visual perempuan tersebut terdapat empat perempuan, yakni dua perempuan tidak berhijab dan dua lainnya berhijab. Menunjukkan bahwa pengguna Wardah kini tidak hanya wanita muslim saja tetapi kemudian Wardah ingin melebarkan segmentasinya ke seluruh kalangan.Kedua, pakaian dan warnanya. Pakaian yang dikenakan oleh model yang berhijab dalam iklan ini adalah pakaian yang tertutup, tidak menampakkan aurat dan tetap modern. Kemudian dua model yang tidak berhijab, pakaian yang dikenakannya juga sopan dan tetap anggun. Warna pakaian yang dikenakan merupakan warna-warna pastel atau warna yang cerah dengan dominan warna biru yang merupakan ciri khas warna dari Wardah sendiri. Penggunaan 
warna yang cerah menandakan bahwa Wardah memberikan keceriaan, ketenangan, percaya diri dan juga santai.Ketiga Logo halal yang terdapat dipojok kanan bawah produk Wardah. Logo halal menandakan bahwa produk tersebut aman untuk dipakai.

d) Kode Proaretik, Dalam voice over tersebut diisi oleh suara Dewi Sandra. Penataan voice over memiliki jeda yang lama dari voice over satu dengan yang lainnya. Menandakan bahwa dalam iklan tersebut, Wardah ingin menyampaikan momen-momen kebaikan dari tiap wanita yang Wardah dampingi dalam tiap scene. Wardah menjadi salah satu penguat karakter dari tiap wanita dalam iklan. Dalam teks tersebut disebutkan juga bahwa "kebaikan dimulai dari yang halal" yang berarti bahwa label halal tersebut menjadi titik poin penting dalam Wardah. Halal kini diidentikkan dengan rasa aman bagi pemakainya. Untuk itu dalam seluruh iklan Wardah tak lepas dari logo halal.

e) Kode Budaya, terdapat dua segmen yang menjadi pembahasannya, pertama membantu orang yang lebih tua, sebuah hal positif tentang pelajaran etika yang ingin disampaikan Wardah dalam iklannya yakni nampak dalam adegan dimana seorang perempuan membantu membawa tas yang dibawa oleh seorang nenek. Selain itu perempuan tersebut juga memberikan tempat duduknya untuk dipakai oleh nenek tersebut.Kedua, mengalah kepada yang lebih muda, divisualkan dalam iklan ini adalah ketika anak kecil adik dan kakak yang sedang berlari-lari membawa ice cream. Tanpa disengaja ice cream milik adiknya terjatuh. Lalu kakak tersebut memberikan ice cream yang dimilikinya kepada adiknya. Pesan moral yang tersampaikan adalah kepada yang lebih muda kita harus mengalah.

2) Wardah BB Cake Powder

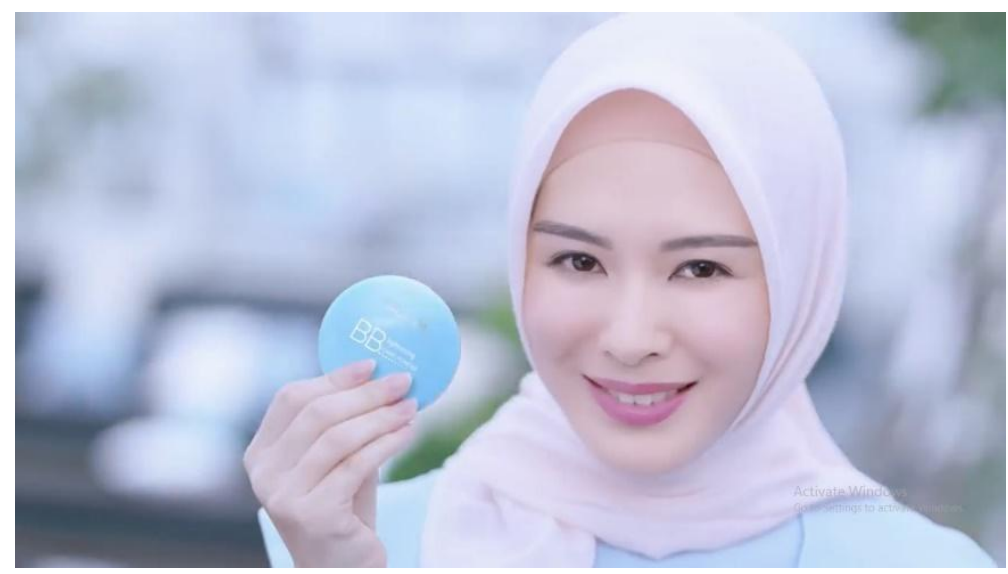

Iklan ini tayang pada televisi dan juga dipublikasikan oleh Wardah pada tanggal 25 Juli 2018 di youtube dengan durasi 15 detik. Dibintangi oleh Ayana Moon JiHye, yang merupakan salah satu spokesperson. Ayana Moon JiHye merupakan selebriti instagram (selebgram) yang memiliki pengaruh luar biasa sebagai influencer bagi orang yang mengikutinya di media sosial. Ayana Moon merupakan mualaf asal Korea Selatan yang kini mulai terkenal dikalangan muslimah khususnya di Indonesia dan Malaysia.

a) Kode Hermeneutik, Iklan ini menceritakan tentang seorang perempuan yang ingin datang ke reuni teman-temannya. Namun ketika hendak berangkat, saat ia melihat bayangannya dikaca nampak mukanya kusam dan berminyak. Lalu untuk menyempurnakan penampilannya, ia memakai produk Wardah BB Cake Powder yang berfungsi menyerap minyak. Ia tampil berani dan cantik tanpa takut mukanya berminyak.

b) Kode Semantik, Senyum pada Ayana Moon merupakan senyum simpul. Senyum simpul merupakan bentuk senyum yang gigi seri bagian atas terlihat dan adanya kontak mata. Mengacu pada konsep penyambutan dan salam terhadap produk baru. Kemudian dengan menggunakan produk tersebut menunjukkan Ayana Moon menjadi perempuan yang mandiri. 
c) Kode Simbolik, diperlihatkan pada tiga hal, pertama Pakaian menutup aurat, sopan dan tetap trendy. Pakaian yang dikenakan model yang berhijab merupakan pakaian menutup aurat dengan atasan berwarna biru yang sesuai dengan warna dari produk Wardah BB Cake Powder yang menurut Leatrice Eisman, seorang konsultan warna memiliki arti kesetiaan, ketenangan, sensitif namun bisa diandalkan.Kedua Membuka produk menggunakan tangan kanan, dengan menggunakan tangan kanan memberikan kesan positif terhadap masyarakat. Selain itu menunjukkan bagaimana tata cara menggunakan produk Wardah serta hal positif yang disampaikan yakni dengan menggunakan tangan kanan.Ketiga, Logo Halal, terdapat logo halal dikanan bawah produk Wardah BB Cake Powder. Yang menandakan bahwa produk tersebut halal dan aman dipakai. Selain itu dengan menggunakan produk halal akan menambah ketertarikan bagi masyarakat khususnya umat muslim.

d) Kode Proaretik, teks pada audio iklan tersebut digunakan untuk menunjukkan pesan secara langsung dan jelas. Pada voice over tersebut dapat dimaknai dengan penegasan yang mengarah pada pembelian produk. Terdapat kata halal pada voice over tersebut mengindikasikan bahwa produk tersebut aman untuk dipakai karena menggunakan bahan-bahan yang tidak berbahaya.

e) Kode Budaya, pakaian yang digunakan wanita muslim. Pakaian yang dikenakan model ketika hendak bertemu dengan teman-temannya adalah pakaian yang modish dan menutup aurat. Busana yang ditampilkan produk Wardah menimbulkan kesan melindungi, bersih, serta sesuai syariat Islam.Kedua, Kerukunan. Wardah ingin menyampaikan hal positif yakni sebuah kerukunan dalam pertemanan.

\section{3) Wardah Ramadhan Cantik dari Hati}

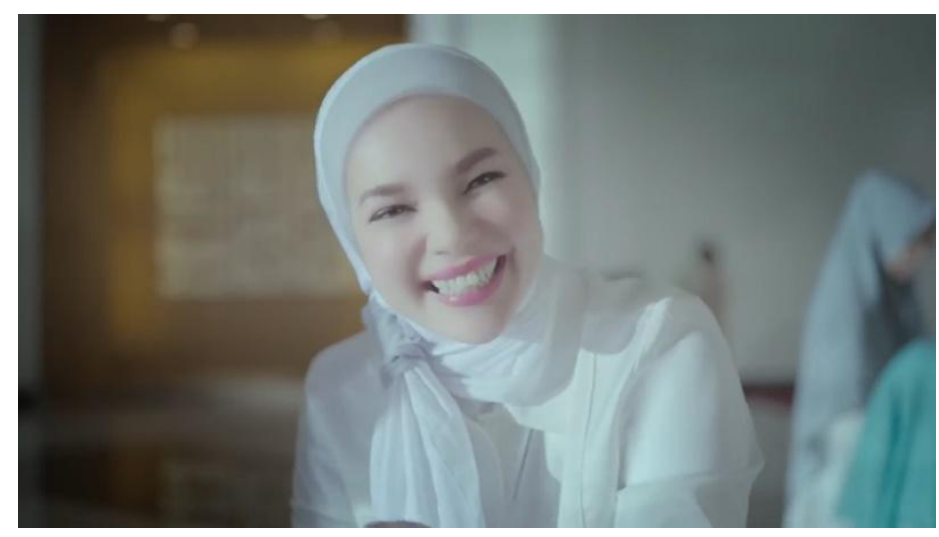

Iklan ini tayang di televisi pada bulan ramadhan di tahun 2018 dan dipublikasikan di Youtube pada tanggal 30 April 2018. Iklan ini dibintangi oleh Sandra Dewi yang merupakan salah satu Brand Ambassador Wardah.

a) Kode Hermeneutik, Iklan ini menampilkan sosok Sandra Dewi yang mengabadikan setiap momen-momen kebaikan yang ditemui disekitar dengan kameranya. Pertama, ketika seorang gadis pengendara motor menabrak bagian belakang mobil, pemilik mobil tidak marah dan menunjukkan sikap yang iklas. Kedua, ketika momen belajar mengajar AlQur'an di masjid, seorang anak kecil nampak takut ustadzah marah padanya karena tidak bisa membaca Al-Qur'an. Namun ustadzah tersebut tersenyum dengan anak kecil tersebut agar ia tidak takut lagi. Ketiga, saat anak-anak kecil bermain tabung besar dan menabrak Dewi Sandra yang akan masuk ke masjid. Dewi Sandra tersenyum melihat anak-anak tersebut.

b) Kode Semantik, Senyum yang ditunjukkan oleh figuran adalah senyum simpul dan senyum lebar. Senyum simpul merupakan senyum dimana kedua bibir pada posisi menutup rapat serta membentuk garis lurus yang terlihat di wajah disertai adanya adanya 
kontak mata. Figur pertama tersenyum sambil mengangguk, menyiratkan bahwa ia memaafkan. Figur kedua dan ketiga tersenyum lebar. Senyum lebar dapat terlihat ketika posisi bibir melebar serta tampak gigi-giginya.Senyuman tipeini mengandung arti kepercayaan diri, energi positif dan kehangatan Senyuman yang lebar juga menandakan keramahan dan ajakan untuk berteman.

c) Kode Simbolik, pertama pakaian dan warnanya, pakaian yang dipakai mengacu kepada objek berupa sebagai identitas agama Islam, yakni menutup aurat. Pakaian yang dikenakan oleh Dewi Sandra adalah dress berwarna putih. Menggambarkan kesan kebebasan dan keterbukaan. Selain itu warna putih juga berarti warna yang murni, suci dan bersih. Pakaian yang digunakan oleh figuran yang lain juga tertutup dan memiliki warna cerah. Menandakan suasana yang tenang, santai, diam, lembut, setia, dan kepercayaan. Kedua, membuka produk menggunakan tangan kanan. Wardah memberi kesan positif terhadap masyarakat tentang bagaimana baiknya menggunakan tangan kanan. Dengan demikian menunjukkan bagaimana tata cara menggunakan produk Wardah serta hal positif yang disampaikan yakni dengan menggunakan tangan kanan.

d) Kode Proaretik, Berdasarkan voice over tersebut menunjukkan produk Wardah yang dipakai oleh Dewi Sandra dapat memberikan kebaikan terhadap orang lain, yakni berupa senyuman. Wardah ingin menunjukkan bahwa cantik selain cantik yang dipoles dengan kosmetik, cantik yang yang dimaksud adalah cantik dari hati.

e) Kode Budaya, Pertama, Sikap tidak mudah marah dan memaafkan, Wardah memberikan pesan positif dalam iklannya di bulan Ramadhan yakni berbagi kebaikan dengan memaafkan kesalahan orang lain. Kedua, Sifat sabar dan ikhlas di bulan Ramadhan, Tujuan puasa yang paling mendasar adalah terbentuknya pribadi bertakwa dengan melaksanakan perintah-Nya dan menjauhi larangan-Nya. Orang muslim yang sedang berpuasa akan ditempa dengan kesabaran. Sabar dengan melaksanakan puasa, menahan lapar, sabar dari menahan hawa dan nafsu. Ketiga, Beri'tikaf di Masjid, kegiatan seperti membantu anak-anak belajar mengaji di masjid, memaafkan kesalahan orang lain, dan menunaikan sholat jamaah di masjid. Wardah ingin menyampaikan hal positif di bulan Ramadhan seperti melakukan amalan sunnah dan berbuat kebaikan kepada orang lain.

4) Wardah Cantik dari Hati - The Power of Smile

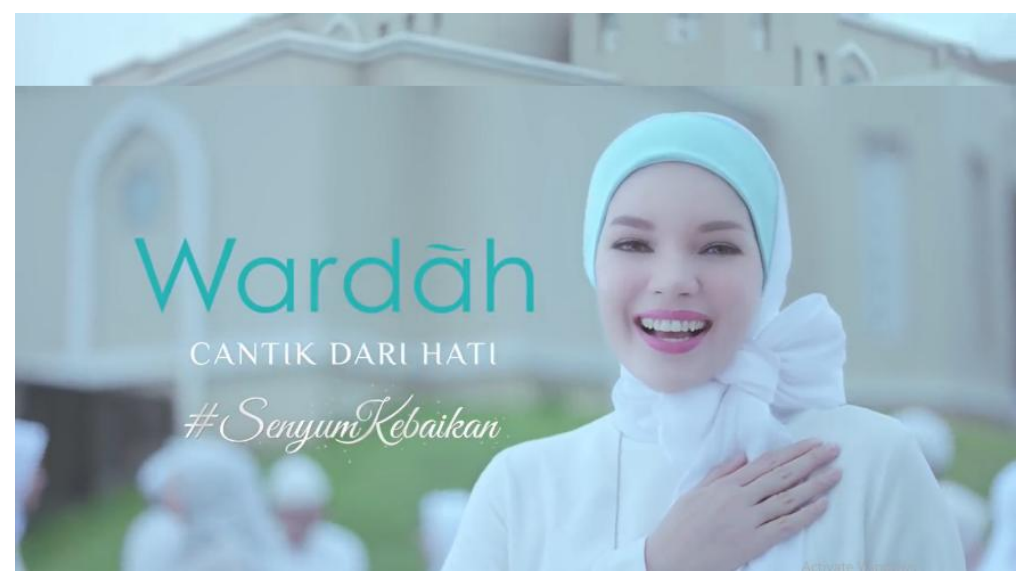

Iklan ini merupakan kelanjutan dari iklan Wardah Cantik dari Hati dengan versi berjudul The Power of Smile yang dibintangi oleh Dewi Sandra juga. Iklan ini dipublikasikan di youtube pada tanggal 9 Juni 2018, dan tayang di televisi pada Hari Raya Idul Fitri tahun 2018. 
a) Kode Hermeneutik, menceritakan tentang suasana hari raya idul fitri. Saat pagi hari orang-orang muslim datang ke masjid untuk menunaikan sholat idul fitri bersama-sama. Nampak suasana yang bahagia terpancar dari wajah orang-orang yang datang ke masjid.

b) Kode Semantik, mengabadikan foto bersama dan tersenyum. Senyum yang terpancar merupakan senyum yang bahagia karena telah mencapai kemenangan bulan Ramadhan. Dewi Sandra dan figur yang lainnya ikut bahagia bersama Wardah dalam momen Idul Fitri.

c) Kode Simbolik, Membuka produk menggunakan tangan kanan, wardah ingin memberikan kesan positif. Menunjukkan bagaimana tata cara menggunakan produk Wardah serta hal positif yang disampaikan yakni dengan menggunakan tangan kanan.Kedua, Pakaian dan warnanya. Pakian yang digunakan merupakan sesuai dengan ajaran Islam. Dalam Islam disunnahkan untuk memakai pakaian yang terbaik yang dimilikinya. Warna yang digunakan dominan putih, yang mengindikasikan kesucian dan kebersihan.Ketiga, Tangan diletakkan didada. Dewi Sandra nampak bahagia dengan menunjukkan senyum lebar. Tangan kanan diletakkan didada, objek mengacu pada sebuah permintaan maaf dan kedamaian.

d) Kode Proaretik, pada voice over menunjukkan Wardah pada Hari Raya Idul Fitri tersebut turut merayakan kemenangan dengan memberikan kebaikan terhadap orang lain. Wardah ingin menunjukkan bahwa cantik selain cantik yang dipoles dengan kosmetik, cantik yang dimaksud adalah cantik yang berasal dari hati.

e) Kode Budaya, Pakaian yang digunakan saat ke Masjid di Hari Raya Idul Fitri. Pakaian yang digunakan ke Masjid saat hendak menunaikan Ibadah Sholat Idul Fitri adalah pakaian yang sesuai syari'at Islam. Warna yang dikenakan pun adalah warna putih berarti bersih, suci dan bercahaya.Bersalam-salaman, selepas melaksanakan shalat id, setiap orang akan berjabat tangan terlebih dahulu untuk saling bermaaf-maafan, bersuka cita, dan mendoakan satu sama lain untuk menunjukkan hubungan persaudaraan yang erat.

5) Wardah Exclusive Matte Lip Cream

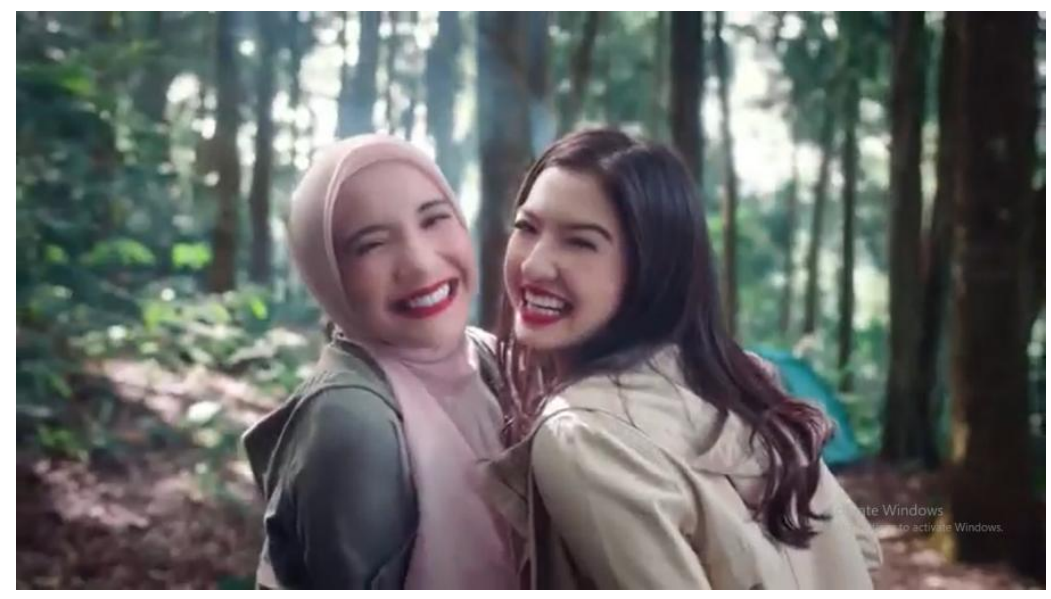

Iklan Wardah Exclusive Matte Lip Cream ini dibintangi oleh Raline Shah dan Zaskia Sungkar. Iklan ini tayang di televisi dan juga dipublikasikan di youtube oleh akun Wardah pada tanggal 7 Maret 2018.

a) Kode Hermeneutik, iklan ini menceritakan tentang persahabatan antara Zaskia Sungkar dan Raline Shah. Mulai dari ketika bermain dan berfoto-foto bersama, makan bersama di Restoran, menghadiri konser band kesukaan bersama-sama. Wardah melengkapi persahabatan dua orang tersebut. 
b) Kode Semantik, ekspresi pada dua model adalah ekspresi yang ceria dan percaya diri. Senyumnya merupakan senyum yang lebar. Senyuman ini merupakan tipe senyuman yang mengandung arti energi yang positif, mempunyai kepercayaan diri, dan kehangatan. Senyuman yang terlihat lebar juga dapat diartikan sebagai ajakan untuk mejalin pertemanan dan sebagai bentuk keramahan. Dalam iklan tersebut ekspresi pada dua model didukung dengan menggunakan produk Wardah.

c) Kode Simbolik, Pertama, menggunakan produk dengan tangan kanan. Memberikan kesan positif terhadap masyarakat tentang bagaimana baiknya menggunakan tangan kanan. Interpretasiyang dimunculkan dapat terlihat dari bagaimana komunikator dalam iklan tersebut dalam menggunakan produk Wardah dengan tata cara yang baik serta hal positif yang disampaikan yakni dengan menggunakan tangan kanan.Kedua, Logo halal. Terdapat logo halal di pojok kiri bawah yang berarti bahwa produk tersebut halal dan aman untuk dipakai oleh seluruh kalangan.Ketiga, Pakaian dan warnanya. Pakian yang dikenakan oleh Zaskia Sungkar merupakan pakaian berhijab yang menutup aurat, sopan, dan tetap modish. Begitu juga dengan pakaian yang digunakan oleh Raline Shah, walaupun ia tidak berhijab namun pakaian yang digunakan sopan, rapi dan tertutup. Warna pakaian yang digunakan adalah warna cerah. Karena iklan ini mempromosikan produk Lip Cream, model memakai pakaian yang soft dan menggunakan produk dengan warna bibir yang mencolok agar penonton terfokus pada produk yang diiklankan.

d) Kode Proaretik. Beberapa istilah yang disebutkan pada voice over merupakan nama-nama dari varian Exclusive Matte Lip Cream Wardah sesuai yang dipakai oleh model pada iklan tersebut. Memberi kesan bahwa Wardah juga turut mewarnai setiap momen Raline Shah bersama dengan Zaskia Sungkar. Dengan berbagai warna dari produk Wardah ini, memberikan kesan yang berbeda dalam setiap momen. Wardah ingin menjadi bagian dalam setiap momen indah setiap wanita.

e) Kode Budaya. Dalam iklan ini divisualkan persahabatan antara Raline Shah dan Zaskia Sungkar yang sangat erat. Mereka melakukan kegiatan bermain bersama dengan mengabadikan momen bersama, makan bersama, dan juga menonton konser bersama. Walaupun salah satu dari mereka berhijab, tidak memberi jarak diantara persahabatan.

\section{E. Makna Konsep Dakwah yang Terkandung dalam Iklan Kosmetik Wardah Tahun 2018}

Setiap produk kosmetik memiliki konsep masing-masing dalam memasarkan produknya. Pada produk Wardah nampaknya terjadi berubahan nilai yang bersifat komersial dalam iklan televisi Wardah. Konsep kosmetik yang halal memiliki arti aman dan kecantikan (dari segi komersial) kemudian diwujudkan dalam iklan. Nilai kecantikan perempuan yang divisualkan dalam iklan merupakan perempuan yang anggun menggunakan pakaian muslim sesuai syari'at Islam. Untuk itu, dalam produk Wardah konsepnya menggunakan nilai agama Islam. Nilai halal dalam label halal produk Wardah merupakan jaminan bahwa produk Wardah aman untuk dipakai.

Konsep cantik wanita berjilbab, yang juga terkandung dalam iklan kosmetik Wardah adalah kecantikan yang tidak hanya dari luarnya saja namun cantik yang berasal dari dalam hati (inner beauty). Cantik dari dalam hati merupakan kecantikan yang dapat memberikan aura kebaikan yang positifuntuk semua orang yang ada disekelilingnya. Sehingga kecantikan yang ditampilkan tidak hanya berupakecantikan fisik saja yang harus dimiliki oleh wanita apalagi muslimah, tetapi juga inner beauty yang merupakan kecantikan dari dalam jiwa dan juga kecantikan diri harus dimiliki oleh kaum wanita untuk menambah kekayaan jiwanya.

Dari beberapai identifikasi konsep Wardah berdasarkan hasil analisa lima iklan televisi Wardah pada tahun 2018 diantaranya:

\section{1) Segmentasi Produk Wajah}

Konsep cerita merujuk kepada segmentasi wanita muslim dan wanita karir. Berdasarkan data Badan Pusat Statistik (BPS) Ketenagakerjaan Indonesia pada Februari 2018, angkatan kerja sebanyak 133,94 juta orang dibanding 2017. Masyarakat yang tidak bekerja dan 
masyarakat yang bekerja menjadi komponen pembentuk dalam angkatan kerja. Fenomena yang terlihat pada bulan februari tahun 2018, terdapat sekitar 6,87 juta jiwa penduduk indonesia yang tidak bekerja atau pengangguran, sedangkan sebanyak 127,07 juta jiwa penduduk Indonesia yang bekerja. Tingkat Partisipasi Angkatan Kerja (TPAK)menjadi meningkatSejalan dengan bertambahnya jumlah angkatan kerja. Terdapat kenaikan $0,18 \%$ poin dari data yang tercatat 69,20\% di bulan Februari 2018 dibandingkan tahun2017. Berdasarkan jenis kelamin, TPAK perempuan sebesar 55,44 persen, meningkat sebesar 0,40 persen poin.

Selain itu berdasarkan survei yang dilakukan oleh Grant Thornton pada tahun 2016 menunjukkan bertambahnya posisi senior pada perusahaan di dunia yang diisi oleh perempuan. Indonesia menempati posisi keenam di dunia yang memberikan posisi tinggi dalam sebuah perusahaan kepada perempuan, yaitu sebesar 36 persen.Hal ini menunjukkan bahwa ketenagakerjaan perempuan di Indonesia semakin meningkat tiap tahunnya. Wardah selain mengambil segmentasi wanita muslim, kini melebarkan kalangannya pada wanita secara umum dengan munculnya beragam iklan produk Wardah dengan model wanita tidak berhijab salah satunya Raline Shah. Hasil analisis menunjukkan bahwa konsep cerita dalam iklan juga merujuk kepada wanita yang memiliki aktivitas padat. Produk-produk Wardah diproduksi sedemikian rupa untuk memenuhi kebutuhan wanita.

\section{2) Logo Halal MUI}

Berdasarkan hasil analisa, terdapat logo halal MUI pada semua iklan Wardah di tahun 2018. Logo halal MUI muncul pada scene terakhir, yang letaknya satu frame dengan produk kosmetik yang diiklankan. Logo berwarna putih dan berukuran kecil.

Sertifikat Halal Majlis Ulama Indonesia yang disingkat MUI merupakan fatwa yang tertulis yang disepakati oleh Majelis Ulama Indonesia, yang di dalamnya menyatakan tentang kehalalan dari suatu produk tertentu yang sesuai dengan batasan yang ditetapkan oleh syari'at Islam. Untuk mencantumkan label halal pada suatu produk kemasan tertentu yang disetujui oleh instansi pemerintah yang mempunyai kewenangan harus mendapatkan Sertifikat Halal terlebih dahulu dari MUI. Sertifikasi Halal MUI pada beberapa produk kosmetik, produk obat-obatan, produk pangan, dan produk lainnya bertujuan untuk memberikan kejelasan status kehalalan suatu produk supaya masyarakat tidak merasa was-was dan khawatir untuk mengkonsumsi suatu produk tersebut. Kesinambungan proses produksi halal dijamin oleh produsen dengan cara menerapkan Sistem Jaminan Halal.

Adanya logo halal pada iklan produk kosmetik Wardah menunjukkan kepada masyarakat bahwa produk Wardah merupakan produk halal sesuai dengan syari'at Islam. Di Indonesia pemeluk agama Islam memiliki persentase 87,2 persen dari populasi total, yang berarti memiliki angka absolut 207,2 juta orang. Karena sebagian besar masyarakat Indonesia merupakan penduduk Islam, hal ini menjadi salah satu alasan Wardah membidik segmentasi wanita muslim dengan label halal. Produk dengan label halal adalah produk yang diproduksi menggunakan bahan-bahan yang aman. Untuk itu, halal identik dengan rasa aman dan nyaman untuk dipakai.

3) Model

Penggunaan model pada iklan Wardah tahun 2018 berdasarkan hasil analisa adalah artis yang memiliki pengaruh pada masyarakat. Yakni sosok yang menarik perhatian masyarakat dan dapat menjadi fantor yang mempengaruhi keputusan masyarakat untuk membeli produk Wardah.

Artis yang digunakan Wardah adalah Raline Shah, Tatjana Saphira, Amanda Rawles, Dewi Sandra, Ayana Moon, Natasha Rizky dan juga Zaskia Sungkar. Model dalam iklan merupakan brand ambassador dan juga spokesperson Wardah. Menjadi seorang publik figur merupakan panutan pagi masyarakat. Apa yang dilakukan, diperbuat, dan disampaikan akan mempengaruhi masyarakat. Baik perilaku sosial maupun keberagaman. 
Pada iklan Wardah tahun 2018 yang dianalisa banyak iklan yang dibintangi oleh Dewi Sandra. Dewi Sandra merupakan publik figur yang berhijrah dengan menggunakan hijab dan total memperkuat sisi spiritualnya di tahun 2012. Sebelum hijrah, dahulunya Dewi Sandra di tahun 2004 merupakan salah satu model majalah dewasa "FHM" Indonesia. Terkesan oleh sikap dan perilakunya, wardah kemudian mengangkat dewi sandra sebagai brand ambassador. begitu juga dengan brand ambassador lainnya, yang perjalanan hidupnya menginspirasi masyarakat.

4) Pakaian

Dengan segmentasi wanita muslim, yang divisualkan Wardah merupakan wanita muslim dengan pakaian yang sopan, tertutup, sesuai syari'at Islam dan modern. Bagi model yang tidak berhijab, pakaian yang digunakan bukan pakaian yang terbuka. Namun pakaian yang tertutup, rapi, sopan, elegan dan juga trendy. Menunjukkan bahwa kini Wardah tidak hanya mengambil segmentasi wanita muslim saja, namun lebih ke wanita secara umum.

Wardah dengan penggunaan model dan juga konsep cerita dalam iklannya kini menunjukkan tidak hanya membidik konsumen wanita muslim saja namun lebih melebarkan segmentasinya ke wanita karir secara umum. Dalam hal pakaian, model yang berhijab dan tidak berhijab dalam iklan tetap menggunakan pakaian yang tertutup, rapi, sopan, serta modern sesuai perkembangan zaman. Hal ini menunjukkan bahwa dengan mulai melebar segmentasinya, Wardah tetap berpegang teguh pada konsep bahwa cantik itu merupakan cantik yang dapat menginspirasi. Bisa jadi wanita telah mengadopsi dinamika perkembangan kemajuan dunia, namun Wardah tetap mengadopsi nilai budaya Timur yang santun.

\section{Kesimpulan}

Setelah dianalisis iklan kosmetik Wardah tahun 2018 dalam mencari makna konsep dakwah, maka peneliti dapat menyimpulkan sebagai berikut: ditemukan berupa kode-kode yang dapat dimaknai sebagai citra produk Wardah. Diantaranya penggunaan model berhijab, adanya simbol halal, dan juga penggunaan warna pada visualisasi simbol-simbol keislaman lain pada iklan.

Konsep dakwah yang terkandung dalam iklan kosmetik Wardah adalah, pertama segmentasi Wardah, yang dulunya memiliki segmentasi wanita muslim kini melebar pada kalangan wanita secara umum. KeduaLabel Halal, Produk dengan label halal adalah produk yang diproduksi menggunakan bahan-bahan yang aman. Penggunaan label halal adalah salah satu bentuk pemasaran wardah. Ketiga model dalam iklan Wardah,adalah artis yang memiliki pengaruh dan menarik perhatian masyarakat dan dapat menjadi fantor yang mempengaruhi keputusan masyarakat untuk membeli produk Wardah. Keempat pakaian yang digunakan model berhijab dalam iklan adalah pakaian yang rapi, sopan, sesuai syari'at Islam, menutup aurat dan tetap trendy. 


\section{DAFTAR PUSTAKA}

An-Nabiry. Fathul Bahry. Meniti Jalan Dakwah Bekal Perjuangan Para Da'i. Jakarta: AMZAH. 2008.

Aripudin, Acep. Sosiologi Dakwah. Bandung; Remaja Rosdakarya. 2013

Aziz. Moh Ali. Ilmu Dakwah cet. ke-4. Jakarta: Prenadamedia Group. 2015.

Bayanuni, Muhammad Abu al-Fath al-. al-Madkhal ila 'Ilm al-Da'wah. Beirut: Muassasah alRisalah, 1993.

el-Ishaq, Ropingi. Pengantar Ilmu Dakwah, Studi Komprehensif Dakwah dari Teori ke Praktik. Malang; Madani. 2016.

Ilaihi. Wahyu. Komunikasi Dakwah. Bandung: PT Remaja Rosdakarya. 2013.

Kasali. Rhenald. Manajemen Periklanan Konsep dan Aplikasinya di Indonesia. Jakarta: Pustaka Utama Grafiti. 1995.

Makaryk dalam Tohar, Vered., Merav Asaf, Anat Kainan, Rakefet Shahar. An Alternative Approach for Personal Narrative Interpretation: The Semiotics of Roland Barthes..International Journal of Qualitative Methods.Vol. 6.No. 3. 2007.

Ma'arif, Bambang S. Psikologi Komunikasi Dakwah. Bandung; Remaja Rosdakarya. 2015.

Sobur. Alex. Semiotika Komunikasi cet. ke 5. Bandung: PT Remaja Rosdakarya. 2013.

Suhandang, Kustadi. Ilmu Dakwah. Bandung; Remaja Rosdakarya. 2013.

Tajibu. Kamaluddin. Syafariana. Pesan Dakwah Pada Iklan Kosmetik Wardah "Sebuah Kajian Semiotika”. 2016.

Wahidah. Faiqatun. Komodifikasi Nilai Agama dalam Iklan Televisi (Studi Analisis Semiotika pada Iklan Wardah). Skripsi Jurusan Komunikasi dan Penyiaran Islam Fakultas Dakwah dan Komunikasi UIN Walisongo Semarang. 2015.

Widyatama. Rendra. Bias Gender dalam Iklan. Yogyakarta: Media Pressindo. 2006. 